\title{
Effects of ozone preconditioning on recovery of rat colon anastomosis after preoperative radiotherapy
}

\author{
İlhan Taşdöven ${ }^{1, A-F}$, Ali Uğur Emre ${ }^{2, B, C, E}$, Fatma Ayça Gültekin ${ }^{2, A-C}$, Muzaffer Önder Öner ${ }^{3, B, C}$, \\ Bekir Hakan Bakkal ${ }^{4, B, C}$, Ümmühani Özel Türkcü̈ ${ }^{\zeta, C, E, F}$ Banu Doğan Gün ${ }^{6, C}$, Gülin Ergun Taşdöven ${ }^{6, D-F}$ \\ 1 Department of General Surgery, Van Training and Research Hospital, Turkey \\ 2 Department of General Surgery, Bülent Ecevit University, Zonguldak, Turkey \\ ${ }^{3}$ Department of Radiation Oncology, Bülent Ecevit University, Zonguldak, Turkey \\ ${ }^{4}$ Department of Medical Biochemistry, Faculty of Medicine, Muğla Sıtkı Koçman University, Turkey \\ ${ }^{5}$ Department of Pathology, Bülent Ecevit University, Zonguldak, Turkey \\ ${ }^{6}$ Department of Otolaryngology, Van Training and Research Hospital, Turkey \\ A - research concept and design; B - collection and/or assembly of data; $\mathrm{C}$ - data analysis and interpretation; \\ $D$ - writing the article; $E$ - critical revision of the article; $F$ - final approval of the article
}

Address for correspondence

İlhan Taşdöven

E-mail: ilhantasdoven1@gmail.com

Funding sources

None declared

Conflict of interest

None declared

Received on April 24, 2017

Reviewed on August 7, 2017

Accepted on June 27, 2019

Cite as

Taşdöven I, Emre AU, Gültekin FA, et al. Effects of ozone preconditioning on recovery of rat colon anastomosis after preoperative radiotherapy. Adv Clin Exp Med. 2019;28(12):1683-1689. doi:10.17219/acem/110329

DOI

10.17219/acem/110329

Copyright

Copyright by Author(s)

This is an article distributed under the terms of the

Creative Commons Attribution 3.0 Unported (CC BY 3.0)

(https://creativecommons.org/licenses/by/3.0/)

\section{Abstract}

Background. Anastomotic leakage is a devastating complication of colorectal surgery. Neoadjuvant radiotherapy for colorectal cancer can affect the mechanical and biochemical parameters of anastomotic healing. It has been reported that ozone increases antioxidant enzyme activity and stimulates adaptive processes to oppose the pathophysiologic conditions mediated by reactive oxygen species (ROS).

Objectives. The objective of this study was to investigate the effect of controlled administration of ozone on the healing of anastomosis and the activation of antioxidant enzymes in the colon after radiotherapy.

Material and methods. Rats $(n=48)$ were randomly assigned to the following groups: control groups (1 and 2), saline-treated and irradiated (IR) groups (3 and 4) and ozone oxidative preconditioning (OOP) and IR groups (5 and 6). Rats were exposed to whole-body IR (6 Gy) after pretreatment with either saline or ozone. Rats in groups 1,3 and 5 were euthanized on postoperative day 3 , whereas those in groups 2,4 and 6 were euthanized on postoperative day 7 . The anastomoses were performed on day 7 post-IR. The anastomotic segment was resected to measure hydroxyproline (HPO) content, myeloperoxidase (MPO) activity and malondialdehyde (MDA) concentration and for histopathological evaluation.

Results. The mean bursting pressure of the groups that underwent radiotherapy was lower than that of the control groups $(p<0.001)$. In groups 5 and 6 , the tissue HPO concentrations were higher than those in groups 3 and 4 . Although mean values for MP0 activity in groups 5 and 6 were higher than those in groups 3 and 4 , the differences were not significant. Regarding oxidative damage markers, MDA concentrations were significantly lower in group 5 than those in group 3 .

Conclusions. In this experimental model, 00P exerted favorable effects on colon anastomotic healing after radiation exposure.

Key words: colon anastomosis, ozone oxidative preconditioning, radiotherapy, anastomotic leakage 


\section{Introduction}

Anastomotic leakage after colorectal surgery is a dreaded complication, as it greatly increases morbidity and mortality and has been associated with high local recurrence and diminished survival after colorectal cancer surgery. ${ }^{1}$ Preoperative radiotherapy is being successfully used as an adjuvant in rectal cancer therapy, but the ionized beams used in radiotherapy can potentially damage organs by increasing the cellular oxidative stress as a result of molecular ionization, leading to the overproduction of reactive oxygen species (ROS) ${ }^{2,3}$ Ozone $\left(\mathrm{O}_{3}\right)$ therapy is widely used in medicine for its antioxidant, anti-inflammatory and antimicrobial effects. ${ }^{4}$ The therapeutic effect of $\mathrm{O}_{3}$ particularly targets reactive oxygen products, hydrogen peroxide and lipid oxidation products (LOPs). ${ }^{5}$ Thus, it has been hypothesized that $\mathrm{O}_{3}$ is effective in preventing ischemia-reperfusion damage and has been used as a therapeutic option in ischemia-reperfusion studies. ${ }^{6,7}$ The term ' $\mathrm{O}_{3}$ oxidative preconditioning' (OOP) implies the triggering of an adaptation to oxidative stress through the application of $\mathrm{O}_{3}$ at repeated non-toxic doses. The claimed efficacy of OOP therapy in preventing ischemia-reperfusion damage in various organs, such as the liver, heart and kidneys, has been demonstrated in experimental studies. ${ }^{6-8}$ We aimed to determine whether the antioxidant capacity of the $\mathrm{O}_{3}$ applied would ameliorate any damage after radiotherapy as well as suppress the anti-inflammatory process at the anastomotic site and to obtain histopathological evidence of this effect.

\section{Material and methods}

This experimental study was conducted after receiving approval from the Animal Research Committee in the Bülent Ecevit University (Zonguldak, Turkey). All animals were handled in accordance with the recommendations of the National Institute of Health Guidelines for the Care and Use of Laboratory Animals (Ankara, Turkey).

\section{Animals and groups}

Forty-eight female Wistar albino rats aged 10-12 weeks and weighing 200-250 g were fed with standard rat feed and fresh potable water ad libitum throughout the study period. They were kept under constant environmental conditions at an average temperature of $21 \pm 1^{\circ} \mathrm{C}$ and humidity of $50-60 \%$ in transparent plastic cages lined with wood shavings. The rats were randomized in a blinded manner to 6 groups comprising 8 rats each.

In control groups (groups 1 and 2), rats were administered $0.5 \mathrm{~mL}$ of intraperitoneal saline for 5 consecutive days. After the administration of the final dose, left colon anastomosis was performed on the rats. On days 3 and 7 following the anastomosis procedure, the rats in group 1 and 2 were euthanized.

In saline-treated and irradiated (IR) groups (groups 3 and 4), rats were administered $0.5 \mathrm{~mL}$ of intraperitoneal saline for 5 consecutive days. A single-dose pelvic IR with 500 cGy was performed $1 \mathrm{~h}$ after the final dose was administered. On day 7 post-IR, left colon anastomosis was performed. After the procedure, the rats were euthanized on day 3 (group 3) and day 7 (group 4).

\section{OOP and IR groups (groups 5 and 6)}

An intraperitoneal injection containing a mixture of $0.7 \mathrm{mg} / \mathrm{kg}$ of $\mathrm{O}_{2} / \mathrm{O}_{3}$ gas was administered each day for 5 consecutive days. A single-dose pelvic IR with 500 cGy was performed $1 \mathrm{~h}$ after the final dose was administered. On day 7 post-IR, left colon anastomosis was performed. The rats were euthanized on day 3 (group 5) and day 7 (group 6) after the procedure. The presence/absence of any complications related to the wounded area in rats and any intra-abdominal abscess, anastomotic leakage or stenosis was also noted. Evaluations of the bursting (blast) pressure and hydroxyproline (HPO) concentration during the anastomosis as well as those of the histopathological and biochemical aspects were performed. During the biochemical examination, malondialdehyde (MDA), myeloperoxidase (MPO) and superoxide dismutase (SOD) concentrations were examined as the oxidative markers in the tissue.

\section{Surgical procedure}

No bowel preparation was preoperatively applied to the rats. To induce dissociative anesthesia, $80 \mathrm{mg} / \mathrm{kg}$ of ketamine $\mathrm{HCl}$ (Ketalar ${ }^{\circledR}$ vial; Eczacıbașı Pharmaceutical Industry and Trade Inc., Lüleburgaz, Turkey) and $10 \mathrm{mg} / \mathrm{kg}$ of xylazine $\mathrm{HCl}$ (Rompun ${ }^{\circledR} 2 \%$; Bayer, Leverkusen, Germany) were intramuscularly injected into each rat. The laparotomy procedure was performed through a 4-centimeter standard mid-line incision. Left colon is transected with a scalpel to perform an anastomosis. Vascular supply of colonic edges is preserved. Colonic contents were cleaned up $2 \mathrm{~cm}$ proximally and distally using the stripping method. To minimize the effect of the suturing material on anastomotic healing, 6/0 non-absorbable monofilament roundneedle polypropylene sutures were used. An edge-to-edge anastomosis procedure was performed, with approx. 6-8 pieces of primary interrupted sutures.

\section{$\mathrm{O}_{3}$ production}

Ozone was generated by an $\mathrm{O}_{3}$ generator (Bozon $\mathrm{N}$; Econica, Odessa, Ukraine), allowing control of the gas flow rate and $\mathrm{O}_{3}$ concentration in real time, using a built-in ultraviolet spectrometer; it was immediately administered at a dose of $1.2 \mathrm{mg} / \mathrm{kg}$ daily via an intraperitoneal route. The volume of the injected mixture was approx. $1 \mathrm{~mL}$. 
The OOP was performed with 5 applications (once daily) of the $\mathrm{O}_{3} / \mathrm{O}_{2}$ mixture. The $\mathrm{O}_{3}$ flow rate was kept constant at $3 \mathrm{~L} / \mathrm{min}$, representing a concentration of $60 \mathrm{mg} / \mathrm{mL}$ and a gas mixture of $97 \% \mathrm{O}_{2}+3 \% \mathrm{O}_{3}$. Tygon polymer tubes and single-use silicon-treated polypropylene syringes $\left(\mathrm{O}_{3}\right.$ resistant) were used throughout the experiment to ensure containment of $\mathrm{O}_{3}$ and consistency of concentration. ${ }^{9}$

\section{Euthanasia}

Groups 1, 3 and 5 were euthanized on postoperative day 3 , while groups 2,4 and 6 were euthanized on postoperative day 7 using the intra-cardiac blood collection method. After the bursting (blast) pressure was measured, the colon segment was resected, including $2 \mathrm{~cm}$ of the proximal and $2 \mathrm{~cm}$ of the distal part of the anastomotic line. Then, it was divided into 2 equal parts vertically passing through the middle of the anastomosis. For the histopathological examination, a section of tissue, including the anastomosis, was placed in $10 \%$ formaldehyde solution. Another section was frozen at $-80^{\circ} \mathrm{C}$ for measuring $\mathrm{HPO}, \mathrm{MPO}$, SOD, and MDA concentrations.

\section{Measurement of the bursting (blast) pressure}

To measure the bursting pressure, an infusion pump (Infusion pump Hospira Plum A+; Abbott, Irving, USA), a pressure transducer (Transpac IV, Abbott) and a monitor (Petas KMA 460-R; Petas, Ankara, Turkey) were provided. The proximal end of the anastomosis was transected, and the fecal content within (if any) was removed. A 6-Fr catheter that was connected to the monitor along with the pressure transducer was placed within the anastomosis. To avoid any air or fluid leakage, the catheter was fixed with a $2 / 0$ silk suture, and a closed system was established. Fluid was transferred from the catheter placed in the proximal part of the colon by means of a perfusion pump at a speed of $50 \mathrm{~mL} / \mathrm{h}$, and the pressure was tracked on the monitor. Fluid leakage or a sudden decline in pressure in the course of the blast at the anastomosis site was determined, and the monitor indicator at that moment was recorded as the bursting (blast) pressure of anastomosis.

\section{Radiation procedure}

A single pelvic IR with 500 cGy was applied to the rats while they were in the prone position by a masked investigator. A computed tomography (CT) simulation of a rat anatomy was performed in 1-millimeter slices, and a dose calculation was performed with the help of Eclipse Treatment Planning System v. 8.9 (Varian Medical Systems, Palo Alto, USA). The animals were brought back to their cages in the post-IR period. The animals in the group 1 and 2 . were anesthetized but not exposed to radiation.

\section{Biochemical examinations}

Biochemical analyses were performed in the Research Laboratory of Nutrition and Dietetics in Muğla Health College, Muğla Sitkı Koçman University, Turkey. Hydroxyproline concentrations in the tissue were measured according to a modification of the method of Jamall et al. ${ }^{10}$ After being weighed, the samples were hydrolyzed with $6 \mathrm{~N} \mathrm{HCl}$ in an autoclave (Nüve OT4060; Nüve Sanayi Malzemeleri, Izmir, Turkey) at $121^{\circ} \mathrm{C}$ for $15 \mathrm{~min}$. Twenty-five microliter of hydrolysate were taken and lyophilized and then were dissolved in $1 \mathrm{~mL} \mathrm{50 \%} \mathrm{(v/v)} \mathrm{isopropyl} \mathrm{alcohol.}$ Chloramine- $\mathrm{T}$ was added to these samples $10 \mathrm{~min}$ later. Then, $1 \mathrm{~mL}$ of Ehrlich solution was added, and the samples were incubated at $50^{\circ} \mathrm{C}$ for $90 \mathrm{~min}$.

Under the same circumstances, 0.4-, 0.8-, 1.2-, and 1.6-microgram L-HPO standards were studied. The color change that occurred during the reaction was spectrophotometrically measured at a 560-nanometer wavelength (PG Instruments T80+; PG Instruments Limited, Leicestershire, UK). Hydroxyproline levels were calculated from a standard curve prepared from L-HPO and expressed as microgram per gram tissue ( $\mu \mathrm{g} / \mathrm{g}$ tissue). ${ }^{10,11}$

Tissue MDA concentrations was measured in a 96-well microliter plate using an enzyme-linked immunosorbent assay (ELISA) kit (Cusabio Biotech Co., LTD., Newark, USA) according to the manufacturer's guidelines. Tissues were homogenized (Pro-Scientific 200; Pro-Scientific, Oxford, USA) in phosphate-buffered saline (PBS). The homogenates were centrifuged for $5 \mathrm{~min}$ at 5,000 $\times \mathrm{g}$ (Eppendorf 5804R; Eppendorf, Hamburg, Germany). The supernatants were used for the determination of MDA levels. Optical density of each well was measured with a microplate plate reader at $450 \mathrm{~nm}$ absorbance (Biorad Model 680 microplate reader; Biorad, Hercules, USA). The sensitivity of the assay was $7.81 \mathrm{pmol} / \mathrm{mL}$ and the linear range of the standard was $31.25-2,000 \mathrm{pmol} / \mathrm{mL}$. The intra-assay and inter-assay coefficients of variation were $<8 \%$ and $<10 \%$, respectively. The concentrations of MDA were represented as nanomoles per milligram protein ( $\mathrm{nmol} / \mathrm{mg}$ protein).

Tissue MPO concentrations were measured in a 96-well microliter plate, using an ELISA kit (USCN Life Science, Wuhan, China) according to the manufacturer's guidelines. Tissues were homogenized (Pro-Scientific 200; ProScientific Oxford, USA) in ice-cold PBS. The homogenates were centrifuged for $5 \mathrm{~min}$ at 5,000 $\times \mathrm{g}$ (Eppendorf 5804R). The supernatants were used to determine MPO concentrations. Optical density of each well was measured with a microplate plate reader at $450 \mathrm{~nm}$ absorbance (Biorad Model 680 microplate reader). The concentrations of MPO were represented as nanogram per milligram protein (ng/mg protein).

Tissue SOD activity was measured using the spectrophotometric method developed by Sun et al. ${ }^{12}$ Tissues were homogenized (Pro-Scientific 200) in PBS were centrifuged for $5 \mathrm{~min}$ at 5,000 $\times \mathrm{g}$ (Eppendorf 5804R). Supernatant were 
mixed to equal volume chloroform/ethanol (3:5 ratio) and centrifuged (Eppendorf $5804 \mathrm{R}$ ) at $5000 \times \mathrm{g}$ for $2 \mathrm{~h}$ at $4^{\circ} \mathrm{C}$. Then, SOD activity and protein levels were measured in supernatants. One unit of SOD was defined as the amount of enzyme causing $50 \%$ inhibition of the reduction rate of nitroblue tetrazolium. Superoxide dismutase activity was given as units $(\mathrm{U}) / \mathrm{mg}$ protein.

Total protein content of tissues was measured using the method of Lowry et al. ${ }^{13}$ with BSA as a standard.

\section{Histopathological evaluation}

From the tissue samples in $10 \%$ formaldehyde solution, paraffin-embedded blocks were prepared and sections of 4-5-micron thickness were stained with hematoxylin and eosin (H\&E). The sections were then evaluated under light microscopy (Leica DMLS; Leica Camera AG, Wetzlar, Germany) by a single pathologist in a blinded manner. Mucosal wound recovery was scored according to the scale proposed by Houdart et al. ${ }^{14}$ Granulocyte infiltration, mononuclear cell infiltration, fibroblastic proliferation, focal necrosis, and exudate formation pertaining to the anastomotic wound recovery were evaluated and scored according to the modified parameters ${ }^{14,15}$ as: 0 - none, 1 - mild, 2 - moderate, and 3 - severe.

\section{Statistical analysis}

Statistical analyses were performed using SPSS v. 13.0 (SPSS, Inc., Chicago, USA) statistical software. For continuous variables with the normal distribution, the ShapiroWilk test was used, whereas in 3 or more group comparisons of the variables showing non-normal distribution, the Kruskal-Wallis test was used. For group comparisons, the Mann-Whitney U test was used. P-values $\leq 0.05$ were considered statistically significant.

\section{Results}

When the groups were evaluated in terms of the bursting pressure, the bursting pressure of the groups that underwent radiotherapy (groups 3-6) was lower than that of the control groups (groups 1 and 2) (p < 0.001). The bursting pressures in the group that received OOP prior to IR were significantly higher than those in the groups treated with saline prior to IR ( $\mathrm{p}<0.001)$. The distribution of the bursting pressure values of anastomosis according to the groups is shown in Fig. 1 and Table 1.

The tissue HPO concentrations in the groups that were treated with saline prior to irradiation were lower than those in the control groups $(\mathrm{p}<0.05)$. Conversely, the HPO values of groups 5 and 6 were statistically higher than those of groups 3 and 4 (Fig. 2).

The MDA concentrations of the groups that underwent radiotherapy (groups 3-6) were higher than those
Table 1. Distribution of the bursting (blast) pressure and standard deviation (SD). Values of anastomosis by group

\begin{tabular}{|l|c|c|c|c|}
\hline Groups & $\begin{array}{c}\text { Average bursting (blast) } \\
\text { pressure (mm Hg) } \pm \text { SD }\end{array}$ & Median & $\begin{array}{c}\text { Mini- } \\
\text { mum }\end{array}$ & $\begin{array}{c}\text { Maxi- } \\
\text { mum }\end{array}$ \\
\hline Group 1 & $145.38 \pm 12.716$ & 144.5 & 123 & 162 \\
\hline Group 2 & $149.63 \pm 37.489$ & 157.5 & 90 & 192 \\
\hline Group 3 & $50.75 \pm 18.722$ & 52.5 & 15 & 75 \\
\hline Group 4 & $74.13 \pm 25.737$ & 84.0 & 40 & 104 \\
\hline Group 5 & $86.00 \pm 19.479$ & 82.5 & 60 & 118 \\
\hline Group 6 & $140.88 \pm 31.832$ & 142.5 & 90 & 185 \\
\hline
\end{tabular}

of the control groups (groups 1 and 2); however, the difference was statistically significant only in the comparison between group 3 and the control groups $(p=0.014)$. Similarly, although a decrease in the MDA concentrations of groups 5 and 6 was maintained, a statistically significant decline was observed in the MDA concentrations of group $5(\mathrm{p}=0.014)$ in comparison with those of groups 3 and 4 (Fig. 3).

The MPO concentrations in the groups that underwent radiotherapy (groups 3-6) were lower than those in the control groups (groups 1 and 2). The increase in the MPO concentrations in the group that underwent

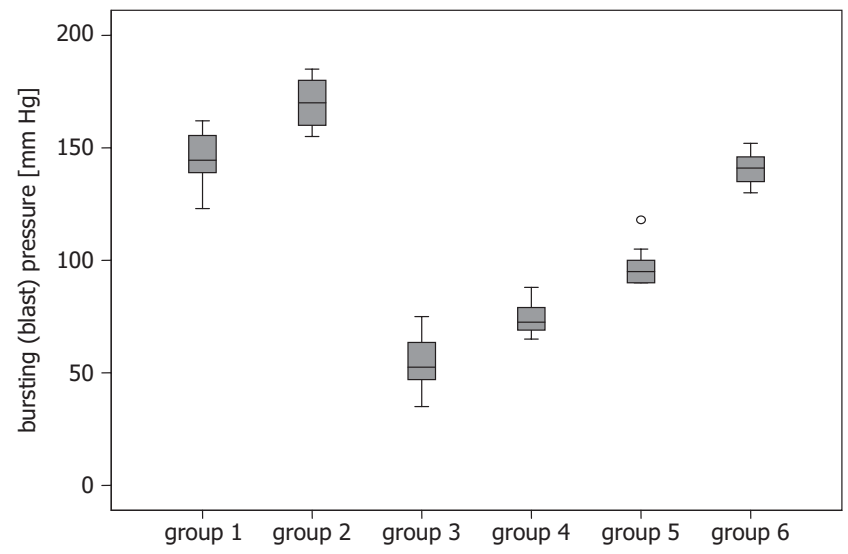

Fig. 1. Distribution of the bursting (blast) pressure values of anastomosis by group

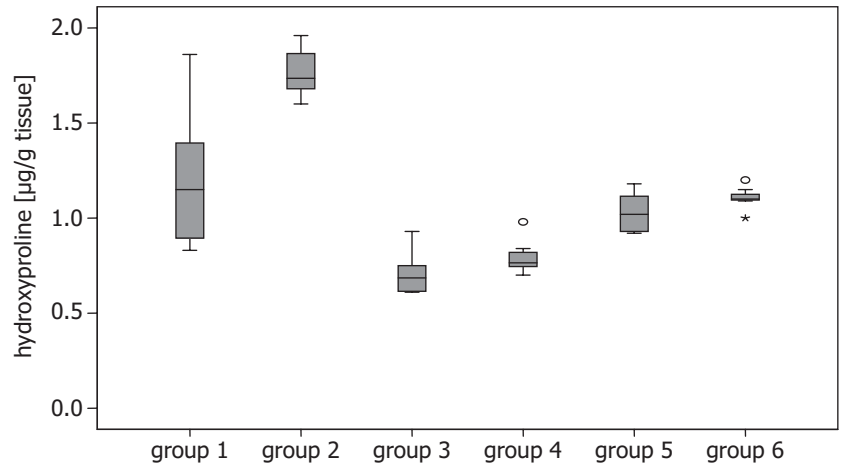

Fig. 2. Hydroxyproline (HPO) concentrations in the anastomotic tissue by group $[\mu \mathrm{g} / \mathrm{g}$ tissue] 


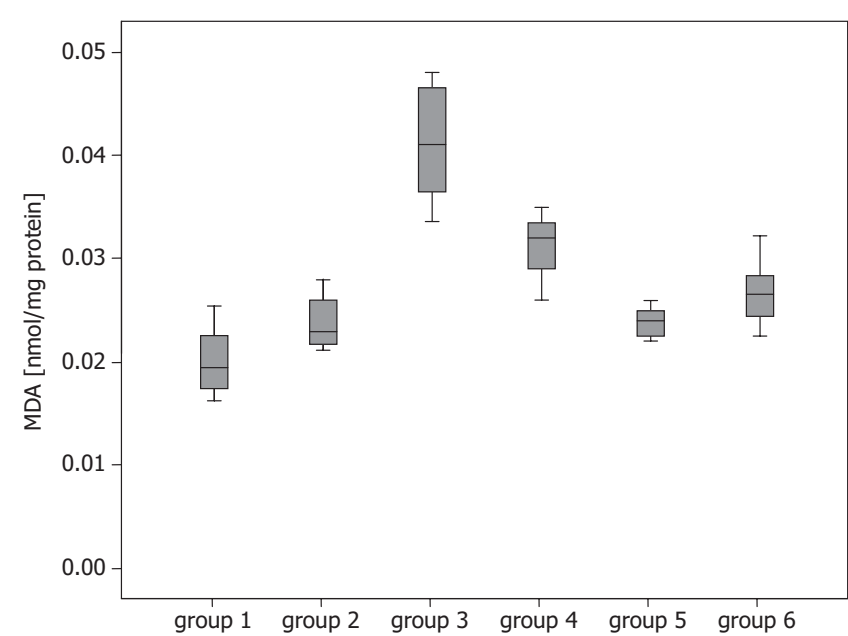

Fig. 3. Malondialdehyde (MDA) levels in the anastomotic tissue by group [nmol/mg protein]

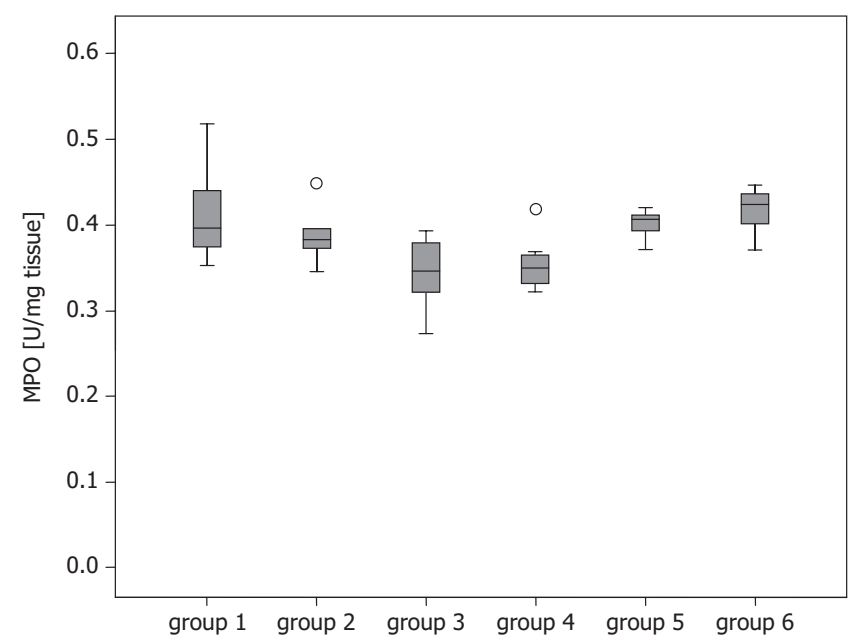

Fig. 4. Myeloperoxidase (MPO) concentrations in the anastomotic tissue by group [ng/mg protein]

OOP (groups 5 and 6) compared with those in the groups treated with saline was only clinically significant. There were no statistically significant differences between the groups (Fig. 4).

The tissue SOD concentrations of groups 3 and 4 were lower than those of groups 1 and 2 ( $p<0.05)$. Conversely,

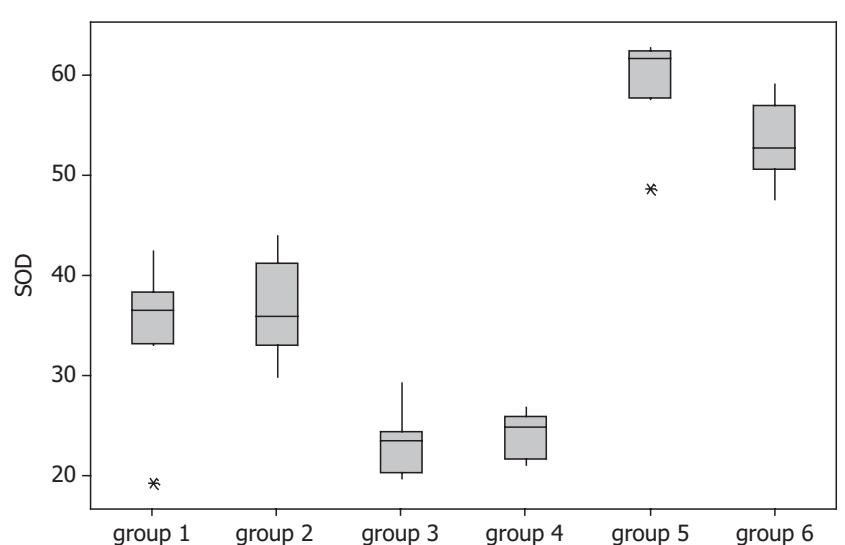

Fig. 5. Superoxide dismutase (SOD) activities in the anastomotic tissue by group [U/mg protein]

the SOD concentrations of groups 5 and 6 were statistically higher than those of groups 3 and 4 ( $\mathrm{p}<0.05)$ (Fig. 5). Table 2 shows the HPO, MDA, MPO, and SOD concentrations in the anastomotic tissues in control and saline- or $\mathrm{O}_{3}$-treated irradiated groups euthanized on day 3 or day 7 after IR.

Upon examining the anastomotic wound healing, granulation tissue development and histological changes corresponding to the local inflammatory response of the study groups (scored from 0 to 4), we observed that the inflammatory cell infiltration in all groups was more intense than in the control groups. The fibroblastic proliferation between the groups was similar; however, it was not statistically significant (Table 3 ).

\section{Discussion}

Anastomotic leakage is one of the major and devastating complication of colorectal surgery. The occurrence of postoperative anastomotic leakage can vary between $10 \%$ and $20 \% .{ }^{16}$ Ischemia is regarded as one of the causes of anastomotic leakage. Wound recovery is negatively affected by hypoxia. ${ }^{17}$

Cronin et al. reported that during the measurements of bursting pressure of the anastomosis, the force to be

Table 2. HPO [ $\mathrm{\mu g} / \mathrm{g}], \mathrm{MDA}[\mathrm{nmol} / \mathrm{g}], \mathrm{MPO}[\mathrm{nmol} / \mathrm{mg}]$, and SOD [U/g] concentrations in the anastomotic tissue by group in control, and saline- or ozonetreated irradiated groups euthanized on day 3 or day 7 after IR. Each group consisted of 6 rats

\begin{tabular}{|c|c|c|c|c|c|c|}
\hline \multirow{3}{*}{$\begin{array}{c}\text { Oxidative stress } \\
\text { markers }\end{array}$} & \multicolumn{2}{|c|}{ Control } & \multicolumn{4}{|c|}{ IR } \\
\hline & \multirow{2}{*}{$\begin{array}{c}\text { day } 3 \\
\text { group } 1\end{array}$} & \multirow{2}{*}{$\begin{array}{c}\text { day } 7 \\
\text { group } 2\end{array}$} & \multicolumn{2}{|c|}{ day 3} & \multicolumn{2}{|c|}{ day 7} \\
\hline & & & $\begin{array}{l}\text { saline-treated } \\
\text { group } 3\end{array}$ & $\begin{array}{l}\text { ozone-treated } \\
\text { group } 5\end{array}$ & $\begin{array}{l}\text { saline-treated } \\
\text { group } 4\end{array}$ & $\begin{array}{l}\text { ozone-treated } \\
\text { group } 6\end{array}$ \\
\hline $\mathrm{HPO}[\mu \mathrm{g} / \mathrm{g}]$ & $1.071 \pm 0.241$ & $0.912 \pm 0.100$ & $0.786 \pm 0.129$ & $0.942 \pm 0.165$ & $0.896 \pm 0.158$ & $1.025 \pm 0.098$ \\
\hline MDA [nmol/mg] & $0.021 \pm 0.111$ & $0.296 \pm 0.092$ & $0.396 \pm 0.093$ & $0.442 \pm 0.076$ & $0.422 \pm 0.135$ & $0.496 \pm 0.090$ \\
\hline MPO [nmol/mg] & $0.357 \pm 0.111$ & $0.296 \pm 0.092$ & $0.396 \pm 0.093$ & $0.442 \pm 0.076$ & $0.422 \pm 0.135$ & $0.496 \pm 0.090$ \\
\hline $\mathrm{SOD}[\mathrm{U} / \mathrm{g}]$ & $34.66 \pm 6.86$ & $36.86 \pm 4.83$ & $23.22 \pm 3.07$ & $59.36 \pm 4.75$ & $24.16 \pm 2.18$ & $53.24 \pm 3.84$ \\
\hline
\end{tabular}

HPO - hydroxyproline; MDA - malondialdehyde; MPO - myeloperoxidase; SOD -superoxide dismutase; IR - irradiation. 
Table 3. Histological changes in the anastomotic tissue by group in control, and saline- or ozone-treated irradiated groups euthanized on day 3 or day 7 after irradiation (IR). Each group consisted of 6 rats

\begin{tabular}{|c|c|c|c|c|c|c|c|}
\hline \multirow{5}{*}{$\begin{array}{l}\text { Granulocyte } \\
\text { infiltration }\end{array}$} & Score & Group 1 & Group 2 & Group 3 & Group 4 & Group 5 & Group 6 \\
\hline & 0 & 0 & 0 & 1 (12.5\%) & $2(25.0 \%)$ & $4(50.0 \%)$ & $3(37.5 \%)$ \\
\hline & 1 & $3(37.5 \%)$ & $4(50.0 \%)$ & $4(50.0 \%)$ & $5(62.5 \%)$ & $4(50.0 \%)$ & 5 (62.5\%) \\
\hline & 2 & 1 (12.5\%) & $3(37.5 \%)$ & $2(25.0 \%)$ & $1(12.5 \%)$ & 0 & 0 \\
\hline & 3 & $4(50.0 \%)$ & 1 (12.5\%) & 1 (12.5\%) & 0 & 0 & 0 \\
\hline \multirow{5}{*}{$\begin{array}{l}\text { Mononuclear } \\
\text { cell infiltration }\end{array}$} & Score & Group 1 & Group 2 & Group 3 & Group 4 & Group 5 & Group 6 \\
\hline & 0 & 0 & 0 & 2 (25.0\%) & 1 (12.5\%) & 0 & 0 \\
\hline & 1 & $6(75.0 \%)$ & $2(25.0 \%)$ & $4(50.0 \%)$ & $5(62.5 \%)$ & 7 (87.5\%) & 7 (87.5\%) \\
\hline & 2 & $2(25.0 \%)$ & $3(37.5 \%)$ & $1(12.5 \%)$ & $2(25.0 \%)$ & 1 (12.5\%) & $1(12.5 \%)$ \\
\hline & 3 & 0 & $3(37.5 \%)$ & 1 (12.5\%) & 0 & 0 & 0 \\
\hline \multirow{5}{*}{$\begin{array}{l}\text { Fibroblastic } \\
\text { proliferation }\end{array}$} & Score & Group 1 & Group 2 & Group 3 & Group 4 & Group 5 & Group 6 \\
\hline & 0 & 0 & 0 & $2(25.0 \%)$ & $1(12.5 \%)$ & 0 & 0 \\
\hline & 1 & $7(87.5 \%)$ & $1(12.5 \%)$ & $4(50.0 \%)$ & $4(50.0 \%)$ & $6(75.0 \%)$ & $4(50.0 \%)$ \\
\hline & 2 & $1(12.5 \%)$ & $3(37.5 \%)$ & $2(25.0 \%)$ & $3(37.5 \%)$ & $2(25.0 \%)$ & $3(37.5 \%)$ \\
\hline & 3 & 0 & $4(50.0 \%)$ & 0 & 0 & 0 & 1 (12.5\%) \\
\hline \multirow{5}{*}{ Focal necrosis } & Score & Group 1 & Group 2 & Group 3 & Group 4 & Group 5 & Group 6 \\
\hline & 0 & $8(100 \%)$ & $6(75.0 \%)$ & 7 (87.5\%) & $8(100 \%)$ & 7 (87.5\%) & 8 (100\%) \\
\hline & 1 & 0 & $2(25.0 \%)$ & 0 & 0 & $1(12.5 \%)$ & 0 \\
\hline & 2 & 0 & 0 & $1(12.5 \%)$ & 0 & 0 & 0 \\
\hline & 3 & 0 & 0 & 0 & 0 & 0 & 0 \\
\hline \multirow{5}{*}{$\begin{array}{l}\text { Exudate } \\
\text { formation }\end{array}$} & Score & Group 1 & Group 2 & Group 3 & Group 4 & Group 5 & Group 6 \\
\hline & 0 & 1 (12.5\%) & $3(37.5 \%)$ & 7 (87.5\%) & $5(62.5 \%)$ & $6(75.0 \%)$ & 5 (62.5\%) \\
\hline & 1 & $3(37.5 \%)$ & $4(50.0 \%)$ & 1 (12.5\%) & $3(37.5 \%)$ & 0 & $2(25.0 \%)$ \\
\hline & 2 & $1(12.5 \%)$ & 0 & 0 & 0 & $2(25.0 \%)$ & $1(12.5 \%)$ \\
\hline & 3 & $3(37.5 \%)$ & $1(12.5 \%)$ & 0 & 0 & 0 & 0 \\
\hline
\end{tabular}

exerted postoperative day 3 onwards tended to increase until it reached its maximum pressure on days $7-10 .^{18}$

It was shown that there was an increase in the re-infusion of the blood mixed with $\mathrm{O}_{3}$ and in the nitric oxide (NO) levels, which caused vasodilatation in the ischemic areas, and that oxidative stress was minimized along with decreased hypoxia, SOD activation and decreased glutathione levels. ${ }^{19,20}$ It has currently been reported that antioxidant enzymes, NO pathways and other cellular activities could be regulated by low doses of $\mathrm{O}_{3} \cdot{ }^{21}$ Controlled administration of $\mathrm{O}_{3}$ can minimize the damage induced by ROS by maintaining the adaptation to OOP or stress. ${ }^{20,22}$ It was reported that $\mathrm{O}_{3}$ would enhance healing in ischemic and ulcerous wounds by promoting expression, secretion and activation of growth factors from the activated thrombocytes. ${ }^{23}$

Stevens et al. compared the cases of anterior resection performed after radiotherapy with 5,000 rad and a group that did not undergo radiotherapy. ${ }^{24}$ They found a significantly higher anastomotic leakage in the radiotherapy group than in the control group; this was consistent with the findings of some other experimental studies reporting negative effect of radiation on anastomotic healing depending on the applied dose and duration. ${ }^{25-27}$
We performed a colon anastomosis on rats on day 7 following the administration of 6 Gy total body IR. During the measurements performed on postoperative days 3 and 7, it was observed that the bursting pressure was lower in the radiotherapy groups than in the control groups $(\mathrm{p}<0.001)$. It was also determined that OOP caused an increase in the bursting pressure, which was significantly higher than that in the saline-treated and IR groups $(\mathrm{p}<0.001)$. It was observed that the tissue HPO concentration in the saline-treated and IR groups (groups 3 and 4) was low compared with that in the control groups $(\mathrm{p}<0.05)$. The HPO concentrations of groups 5 and 6 were significantly higher than those of groups 3 and 4 . Along with these findings, we ascertained that a single, low-dose irradiation performed on preoperative day 7 affected the anastomosis recovery in our rat model.

Our findings regarding the low bursting pressure and HPO concentrations in an experimental rodent model suggest that $\mathrm{O}_{3}$ exposure prior to radiotherapy contributes to a decrease in the incidence of anastomotic leakage after colorectal surgery during the early stage. Although radiotherapy-based damage occurred as the result of oxidative stress, the MDA concentration of group 3 was a significant indicator of oxidative stress among the study groups. 
In other groups, the differences in MDA and MPO values were not significant.

Here, OOP caused the bursting pressure and HPO values to increase in rats during the colon anastomosis procedure. The effect of $\mathrm{O}_{3}$ exposure on the oxidative indicators/markers in the anastomotic tissue was evidenced by a significant decline in MDA concentrations in group 5 . In other groups, the differences in MDA and MPO values were not significant.

Our findings reveal that radiation negatively affected recovery after colonic anastomosis surgery and this is concordant with the results of previous reports. Conversely, based on HPO, SOD and MDA measurements and histopathological examinations, we found that OOP had a positive effect on the recovery of anastomoses performed after radiotherapy. These findings in an experimental rodent model suggest that $\mathrm{O}_{3}$ exposure prior to radiotherapy contributes to a decrease in the incidence of anastomotic leakage after colorectal surgery. However, there is need for further studies to assess the effects and antioxidant capacity of $\mathrm{O}_{3}$.

\section{References}

1. Buchs NC, Gervaz P, Secic M, Bucher P, Mugnier-Konrad B, Morel P. Incidence, consequences, and risk factors for anastomotic dehiscence after colorectal surgery: A prospective monocentric study. Int J Colorectal Dis. 2008;23(3):265-270.

2. Mettler FA, Jr, Voelz GL. Major radiation exposure: What to expect and how to respond. N Eng/ J Med. 2002;346(20):1554-1561.

3. Coleman CN, Blakely WF, Fike JR, et al. Molecular and cellular biology of moderate-dose (1-10 Gy) radiation and potential mechanisms of radiation protection: Report of a workshop at Bethesda, Maryland, 17-18 December 2001. Radiat Res. 2003;159(6):812-834.

4. Bocci V. Physical-chemical properties of ozone. Natural production of ozone. The toxicology of ozone. In: Bocci V, ed. Ozone. A New Medical Drug. Dordrecht, the Netherlands: Springer; 2005:5-8.

5. Bocci V. How does ozone act? How and why can we avoid ozone toxicity? In: Bocci V, ed. Ozone. A New Medical Drug. Dordrecht, the Netherlands: Springer; 2005:19-28.

6. Ajamieh HH, Menéndez S, Merino N, Martínez-Sánchez G, Re L, León $\mathrm{O}$. Ischemic and ozone oxidative preconditioning in the protection against hepatic ischemic-reperfusion injury. Ozone Sci Eng. 2003;25(3):241-250.

7. Barber $E$, Menéndez S, Leon OS, et al. Prevention of renal injury after induction of ozone tolerance in rats submitted to warm ischaemia. Mediators Inflamm. 1999;8(1):37-41.

8. Berson EL, Remulla JF, Rosner B, Sandberg MA, Weigel-Difranco C. Evaluation of patients with retinitis pigmentosa receiving electric stimulation, ozonated blood, and ocular surgery in Cuba. Arch Ophthalmol. 1996;114(5):560-563.
9. Gultekin FA, Bakkal HB, Guven B, et al. Effects of ozone oxidative preconditioning on radiation-induced organ damage in rats. J Radiat Res. 2013;54(1):36-44.

10. Jamall IS, Finelli UN, Que Hee SS. A simple method to determine nanogram levels of 4-hydroxyproline in biological tissues. Anal Biochem. 1981;112(1):70-75.

11. Kivirikko KI, Laitinen O, Prockop DJ. Modifications of a specific assay for hydroxyproline in urine. Anal Biochem. 1967;19(2):249-255.

12. Sun Y, Oberley LW, Li Y. A Simple method for clinical assay of superoxide dismutase. Clin Chem. 1988:34(13):497-500.

13. Lowry OH, Rosebrough NJ, Farr AL, Randall RJ. Protein measurement with the folin phenol reagent. J Biol Chem. 1951;193(1):145-157.

14. Houdart, R, Lavergne, A, Galian, A, Hautefeuille, P. Anatomo-pathological evolution of single-layer end-to-end intestinal anastomoses. A study of 210 colonic anastomoses in the rat, from the $2^{\text {nd }}$ to $180^{\text {th }}$ days [in French]. Gastroenterol Clin Biol. 1983;7(5):465-473.

15. Kuzu MA, Kuzu J, Köksoy C, Aksoy FH, Uzal D. Histological evaluation of colonic anastomotic healing in the rat following preoperative 5 -fluorouracil, fractionated irradiation and combined treatment. Int J Colorectal Dis. 1998;13(5-6):235-240.

16. Phillips JD, Kim CS, Fonkalsrud EW, Zeng H, Dindar H. Effects of chronic corticosteroids and vitamin A on the healing of intestinal anastomoses. Am J Surg. 1992;163(1):71-77.

17. Witte MB, Barbul A. Repair of full-thickness bowel injury. Cri Care Med. 2003; 31(8 Suppl):538-546.

18. Cronin K, Jackson DS, Dunphy JE. Specific activity of hydroxyprolinetritium in the healing colon. Surg Gyn Obst. 1968;126(5):1061-1065.

19. Ajamieh HH, Menéndez S, Martínez-Sánchez G, et al. Effects of ozone oxidative preconditioning on nitric oxide generation and cellular redox balance in a rat model of hepatic ischaemia reperfusion. Liver Int. 2004;24(1):55-62.

20. Peralta C, Leon OS, Xaus C, et al. Protective effect of ozone treatment on the injury associated with hepatic ischemia reperfusion: Antioxidant-prooxidant balance. Free Radic Res. 1999;31(3):191-196.

21. Re L, Mawsouf MN, Menendez S, Leon OS, Sanchez GM, HernandezF. Ozone therapy: Clinical and basic evidence of it's therapeutic potential. Arch Med Res. 2008;39(1):17-26.

22. Leon OS, Menendez S, Merino N, et al. Ozone oxidative preconditioning: A protection against cellular damage by free radicals. Mediators Inflamm. 1998;7(4):289-294.

23. Di Paolo N, Bocci V, Gaggiotti E. Ozone therapy. Int J Artif Organs. 2004;27(3):168-175.

24. Stevens KR, Fletcher WS, Allen CV. Anterior resection and primary anastomosis following high dose preoperative irradiation for adenocarcinoma of the recto-sigmoid. Cancer. 1978;41(5):2065-2071.

25. Pleskovic A, Zorc-Pleskovic R, Vraspir-Porenta O. Colon mucosal cells after combined radiotherapy and chemotherapy. Folia Biol (Praha). 2001;47(5):156-162.

26. Blake DP, Bubrick MP, Kochsiek GG. Low anterior anastomotic dehiscence following preoperative irradiation with 6000 rads. Dis Colon Rectum. 1984;27(3):176.

27. Winsey K, Simon RJ, Levenson S. Effect of supplemental vit-A on colon anastomotic healing in rats given preoperative irradiation. Am J Surg. 1987;153(2):153-156. 